\title{
Too polluted to work? The gendered correlates of air pollution on hours worked

\author{
Guillermo Montt(1)
}

Correspondence: montt@ilo.org Research Department, International Labour Office, 4 route des Morillons, 1211 Geneva, Switzerland

\begin{abstract}
Air pollution affects workers' ability to work by damaging their own health, but also by damaging the health of their dependents. This paper draws on 20 years of air pollution and employment data from Santiago, Chile, a highly polluted metropolis, particularly in fall and winter months. The paper finds that though air pollution is not associated to a reduction in overall hours worked, it does so for women and particularly for women with children. Weeks with pollution at $100 \mu \mathrm{g} / \mathrm{m}^{3}$, common for Santiago, see double the gender difference in working hours. It is hypothesised that children, unable to go to school, must stay home and cared for. These findings suggest that air pollution may contribute to gender inequality through the gendered-biased distribution of care responsibilities. Pollution brings to evidence gender inequalities in care and, given the gendered nature of care and the geographic distribution of pollution, may contribute to enhance gender and geographic labour market inequalities. Environmental policy may serve to enhance gender equality as well.
\end{abstract}

Keywords: Air pollution, Hours worked, Health, Care, Gender

JEL Classification: J22, Q52, Q53

\section{Introduction}

The environment and the world of work are tightly linked. Environmental degradation can, in the long term, hurt jobs through two channels. On the one hand, environmental degradation deteriorates infrastructure and the ecosystem's ability to provide services (i.e. ecosystem services), both of which sustain jobs. On the other hand, environmental degradation has a direct impact on individuals' health (ILO 2018). Excessive heat, indoor and outdoor air pollution, and water and soil pollution, among others, are forms of environmental degradation that affect workers' ability to work through their own illness or, when the care of dependents relies on working individuals, through the illness of their dependents (e.g. children or the frail elderly).

This paper focuses on the effects of urban outdoor air pollution. It takes advantage of 20 years of daily outdoor air pollution and quarterly employment data from Santiago, Chile. Results show that pollution is not associated to aggregate changes in hours worked. The null aggregate result, however, hides a gendered dynamic: when air pollution rises, women-and women with children, in particular-are more likely to work fewer hours. It is hypothesised that men and women can combine care and work

(C) The Author(s). 2018 Open Access This article is distributed under the terms of the Creative Commons Attribution 4.0 International License (http://creativecommons.org/licenses/by/4.0/), which permits unrestricted use, distribution, and reproduction in any medium, provided you give appropriate credit to the original author(s) and the source, provide a link to the Creative Commons license, and indicate if changes were made. 
when healthy children go to school. When sick and unable to attend school, these children must be cared for by someone. In a country like Chile where care for dependents is primarily the responsibility of women within the family, it is the women who reduce their working hours as a result of children falling ill due to air pollution.

The following sections develop further the link between air pollution, hours worked and care for dependents; describe the data sources and methods; and discuss the results.

\subsection{Air pollution, hours worked and care}

Several contaminants produce urban outdoor air pollution. ${ }^{1}$ The most commonly measured are carbon monoxide $(\mathrm{CO})$, nitrogen oxide $\left(\mathrm{NO}_{2}\right)$, ozone $\left(\mathrm{O}_{3}\right)$ and sulphur dioxide $\left(\mathrm{SO}_{2}\right)$. Suspended particulate matter is also considered a pollutant. They are small solid particles in the air (i.e. "floating dust"). Commonly, two groups of suspended particulate matter are measured, according to their size: those with an aerodynamic size smaller than $10 \mu \mathrm{m}\left(\mathrm{PM}_{10}\right)$ and those smaller than $2.5 \mu \mathrm{m}\left(\mathrm{PM}_{2.5}\right)$. Each contaminant is associated to different health hazards including, but not exclusive to, respiratory problems which may be transient or bring about long-term health deterioration (Muñoz 1991). Air in polluted urban areas can also contain heavy metals like lead, which are especially dangerous to children's cognitive and physical development. ${ }^{2}$

Air pollution is the fourth leading fatal health risk worldwide. The World Bank (2016) estimates that the 5.5 million premature deaths associated to air pollution in 2013 led to 225 billion USD in income losses. These costs only consider lost income due to premature deaths, but air pollution also reduces hours worked and productivity as a result of lost working days, which the OECD (2016a) estimates at 1.2 billion USD. Air pollution increases health expenses. Illness-related costs that do not result in mortality-morbidity costs-amount to around 10\% of mortality costs in the case of air pollution (OECD 2014a), resulting in over 100 billion USD in Europe (WHO and OECD 2015). In California, hospital-related expenses that result from air pollution resulted in 193 million USD over the 2005-2007 period (Romley et al. 2010).

Aside from the effects of premature deaths and health care expenses, air pollution affects hours worked through two channels: workers' own health deterioration and dependent caregiving (Aragon et al. 2017). ${ }^{3}$ When pollution levels reach critical levels, workers may be ill and call in sick. In New Delhi, the city with the worst outdoor air pollution level (WHO 2016), for example, 5-10\% of staff report called in sick due to respiratory or breathing problems following the critical pollution episodes in 2016 (ASSOCHAM 2016). The direct effects of critical pollution episodes on labour supply are not limited to the immediate health risks: they persist in the medium term as well (Kim et al. 2017).

A second channel by which air pollution impacts is indirect and operates through dependents (Aragon et al. 2017). Children and the elderly are particularly sensitive to the health effects of pollution, which can manifest themselves through bronchitis, cough and decreased lung function (AAP 2004). When pollution is high, but not critical, workers may still be healthy enough to work, but children and the elderly may fall sick. If care for sick children and dependents relies on working adults, they will likely have to skip work to take care of their dependent children or elderly. This is the case, for example, when children cannot go to school as a result of illness. 
The distribution of care work is gendered-biased, with the bulk of care work falling on women in unpaid arrangements, with some variation across countries (OECD 2014b). If the distribution of care for sick dependents relies on one group of workers, e.g. women, the effects of non-critical yet high air pollution levels on hours worked will fall disproportionately on this group.

Importantly, this indirect effect of air pollution on hours worked only affects individuals who combine paid work and care. Informal family caregivers who care for children or the elderly on a full-time basis are not in paid work, so air pollution will not affect their position in the labour market though it may further limit their possibility to enter the labour market. These indirect effects will only apply in cases in which the carer combines paid work and care, that is, when the standard care arrangement cannot be met when the child or elderly is sick. In countries where childcare, schooling and elderly care is shared between the family and institutions (e.g. nurseries, day care centres), the impact on hours worked will be the strongest (Heymann et al. 2006). The 2002 Community Care and Health Act in Scotland offered free formal personal care to the elderly, increasing the working hours of their family caregivers by an average of 0.4 hours per week, as a result of a reduction in informal care provided (Hollingsworth et al. 2017).

Chile provides an interesting case study for this hypothesis. From age 3 to 5, 75.3\% of children spend their days in pre-primary school. From age 5 onwards, the majority go to school (OECD 2016b). If children fall sick, they have to stay home. If the child's parents work, one of them will have to stay home. It is usually the mother, even in countries with greater levels of gender equality (Eriksson and Nermo 2010). If the household hires a full-time housemaid, working parents need not stay home and the housemaid will care for the child. In contrast to healthy children attending school, few, if any, options exist in Chile to support the care of the frail elderly. Almost $90 \%$ of them stay in their home under the care of a non-working family member (Palacios 2017). ${ }^{4}$ Given the unavailability of institutional care options for the healthy frail elderly, their falling sick may not be related to hours worked since the majority of elderly family caregivers are out of the labour force already.

Santiago, Chile's capital, endures high levels of air pollution during the fall and winter months. Even though summer months have relatively low pollution levels, Santiago still ranks among the most polluted cities in the world (WHO 2016). ${ }^{5}$ Annual average pollution levels systematically exceed the World Health Organization's (WHO) annual $\mathrm{PM}_{10}$ guidelines on all the city's monitoring stations. Roughly 7 million people live in Santiago, in an area of $15,400 \mathrm{~km}^{2}$. During the 1990s, Santiago was among the most polluted cities in the world (O'Ryan and Larraguibel 2000). Pollution levels are not equally distributed throughout the year, with high levels of pollution more common in the fall and winter months. Pollution levels are not equally distributed throughout the city, with higher concentrations of particulate matter and other pollutants (with the exception of ozone) observed in the southern parts of the city.

This paper takes advantage of a continuous quarterly measurement of employment and daily measurement of pollutants in Santiago for 20 years. It draws on the temporal and geographical variation to explore the gendered and care-related relationship between air pollution and hours worked. 


\section{Data and methods}

This paper merges air pollution and labour market data for the urban area of Santiago, Chile, and then regresses hours worked per week on air quality, gender and household composition and other controls to estimate whether the relationship between air pollution and hours worked differs between men and women. ${ }^{6}$

The National Air Quality Information System (SINCA, for Sistema de Información Nacional de Calidad del Aire) provides daily measures for several air pollutants measured in eight monitoring stations distributed across the city in Santiago (monitoring stations also exist for other Chilean cities). Today, measures include ozone $\left(\mathrm{O}_{3}\right)$, sulphur dioxide $\left(\mathrm{SO}_{2}\right)$, carbon monoxide $(\mathrm{CO})$, nitrogen oxide $\left(\mathrm{NO}_{2}\right)$ and particulate matter density $\left(\mathrm{PM}_{10}\right.$ and $\left.\mathrm{PM}_{2.5}\right)$. The $\mathrm{PM}_{10}, \mathrm{SO}_{2}, \mathrm{O}_{3}$ and $\mathrm{CO}$ measurement series for Santiago date back to 1997 in the majority of the city's monitoring stations.

The discussion in this study draws mostly on $\mathrm{PM}_{10}$, which has the longest data series. The correlation between the measured pollutants, with the exception of $\mathrm{O}_{3}$, is relatively high (see Fig. 1 and Additional file 1 for all the measures gathered from the Pudahuel monitoring station; correlations for other pollutants are similar in other stations but not shown).

The Employment and Unemployment Survey in Santiago (EOD for Encuesta Nacional de Ocupación y Desocupación del Gran Santiago) samples around 2500 individuals every March, June, September and December to measure the labour force participation, employment rate, employment conditions, income and hours worked of the population in Santiago for a specific reference week in each quarter. The sample is stratified into eight strata. Each stratum is geographically determined, linked to the administrative boundaries of municipalities. The EOD provides continued labour force statistics since 1957. The

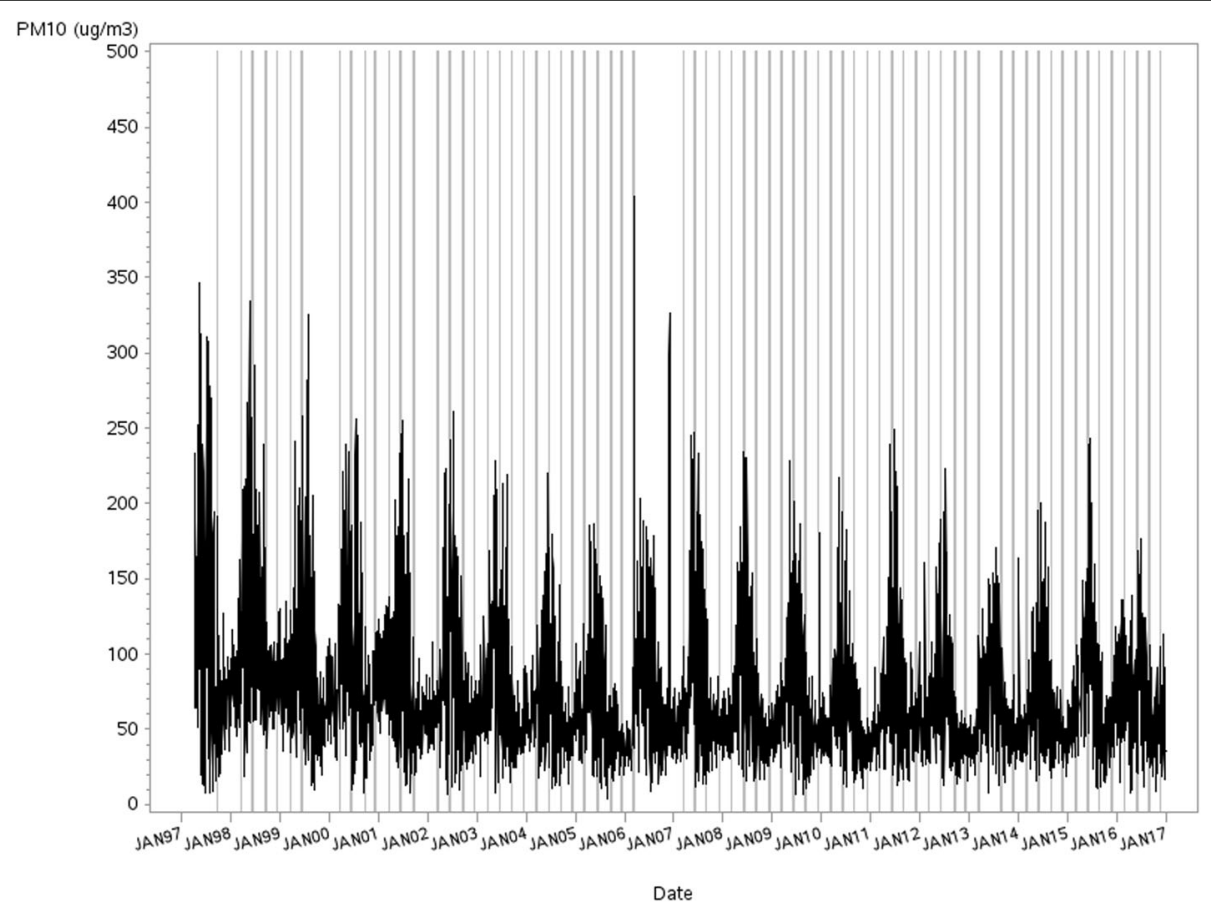

Fig. $1 \mathrm{PM}_{10}$ concentration in Santiago, Chile, 1997-2016. Notes: PM10 in microgrammes per cubic metre. Shaded area corresponds to the week prior to the employment survey reference week. Source: Own elaboration from SINCA, Pudahuel monitoring station 
survey collects information on the labour force and employment status, hours worked, age and gender for all household members. The information in the survey allows identifying the number of children in the home (individuals aged 14 or younger) and the number of dependent elderly in the home (individuals aged 60 or older who are neither the head of the household nor the spouse). To limit the burden on respondents, the survey asks about educational attainment only in the June waves and up until 2008, asked about income in the March and June waves only. Adding income and educational attainment to the models thus reduce the sample size and eliminates important variability. For this reason, neither income nor educational attainment is included in the models, except to assess the robustness of the results.

This study merges the 1997-2017 SINCA and EOD data. The study uses data from seven SINCA monitoring stations located in different municipalities of the Santiago metropolitan region (Cerrillos, El Bosque, Independencia, La Florida, Las Condes, Parque O'Higgins and Pudahuel). Combined, they match each of the strata in the EOD, as per Table 1. The data from the Puente Alto and Quilicura stations are not used due to their shorter data series. For strata not represented by any particular monitoring station (e.g. strata 1 and 4), the average of the closest monitoring stations is used.

As is common in labour force surveys, the EOD asks about respondents' labour market status employment for a specific week in each quarter (i.e. the reference week). It is usually the second week of March, the second or third week of June, the first or fourth week of September and the first or second week of December. For example, for the March 2016 survey, the EOD asked the sample about their employment status between March 6, 2016, and March 12, 2016. The average pollution level from the week prior to the reference week is taken as the relevant air pollution metric as there is a lag between the air pollution level and the associated health deterioration. This strategy matches that of other similar studies, notably Aragon et al. (2017).

Of the 80 quarterly employment surveys carried out between 1997 and 2016, nine are excluded. Eight are excluded because of the unavailability of the specific reference week of the survey (1997Q2, 1997Q4, 1999Q3, 1999Q4, 2001Q4, 2006Q2, 2006Q3, 2006Q4). The 1997Q1 survey is excluded because it precedes the public availability of the pollution trend data, which began on April 1997. A total of 71 employment surveys are used,

Table 1 Matching strata in the employment survey with air pollution monitoring stations

\begin{tabular}{lll}
\hline Strata & Municipalities in the strata & SINCA monitoring station \\
\hline 1 & Nunnoa, La Reina, Macul, Peñalolén & La Florida, Las Condes \\
2 & San Miguel, La Cisterna, San Joaquín, La Granja, San Ramón, & El Bosque \\
3 & Pedro Aguirre Cerda, Lo Espejo & \\
4 & El Bosque, La Pintana, San Bernardo & El Bosque \\
5 & Maipú, Cerrillos, Pudahuel, Lo Prado, Cerro Navia & Pudahuel, Cerrillos \\
6 & Recoleta, Independencia, Conchalí, Renca, Quilicura, Huechuraba & Independencia \\
7 & Providencia, Vitacura, Las Condes, Lo Barnechea & Las Condes \\
8 & Santiago, Estación Central, Quinta Normal & Parque O'Higgins \\
\hline
\end{tabular}

Note: Strata are the primary sampling units in the EOD. Each stratum comprises of between two and seven municipalities which match SINCA monitoring stations. When a stratum is associated to more than one SINCA monitoring station, the average of the two stations is used in the study 
which comprise 787,969 surveyed individuals, of which 255,683 (32\%) worked in the respective reference week.

To estimate the effect of air pollution on hours worked, a baseline model regresses the total number of hours worked by the worker $i$ in strata $s$ in the reference week $w$ on the corresponding strata's weekly average pollution level in the preceding week $\left(\mathrm{P}_{s, w-1}\right)$. The estimate for $\beta_{1}$ identifies the extent to which an increase in pollution in a given week (e.g. an increase in $1 \mu \mathrm{g} / \mathrm{m}^{3}$ in $\mathrm{PM}_{10}$ ) is related to changes in the following week's hours worked.

$$
H_{w, s, i}=\beta_{0}+\beta_{1} P_{s, w-1}+\varepsilon_{w, s, i}
$$

To assess the extent to which air pollution affects women differently, the model interacts gender $\left(\mathrm{F}_{i}\right)$ with pollution levels $\left(\mathrm{F}_{i} \circ \mathrm{P}_{s, w-1}\right)$. In Eq. 2, the estimate for coefficient $\beta_{1}$ identifies the relationship between pollution and men's hours worked, the estimate for coefficient $\beta_{3}$ the differential relationship of air pollution on women's hours worked.

$$
H_{w, s, i}=\beta_{0}+\beta_{1} P_{s, w-1}+\beta_{2} F_{i}+\beta_{3} F_{i} \cdot P_{s, w-1}+\varepsilon_{w, s, i}
$$

A further interaction is added in Eq. 2 to explore whether children in the home $\left(C_{i, w}\right)$, as a proxy for an adult's care demands, relate to hours worked when pollution levels increase. The estimate for $\beta_{6}$ in Eq. 3, associated to the triple interaction between gender, number of children and pollution, captures the differential relationship of pollution on hours worked on women with one child in the home (the estimate for $\beta_{5}$ captures the relationship of pollution on men's hours worked with each additional child in the home).

$$
\begin{aligned}
H_{w, s, i}= & \beta_{0}+\beta_{1} P_{s, w-1}+\beta_{2} F_{i}+\beta_{3} C_{i, w}+\beta_{4} F_{i} \cdot P_{s, w-1}+\beta_{5} P_{s, w-1} \cdot C_{i, w}+\beta_{6} F_{i} \\
& \cdot P_{s, w-1} \cdot C_{i, w}+\beta_{7} F_{i} \cdot C_{i, w}+\varepsilon_{w, s, i}
\end{aligned}
$$

A model evaluates the relationship with an elderly in the home by replacing the number of children $\left(C_{i, w}\right)$ by the number of elderly in the household who are neither the household head nor the spouse. To check whether childcare is the main driver of the relationship, an additional model controls for whether the household includes a non-working adult who could, potentially, care for the sick child or elder when they fall sick.

All models include controls for worker's age and economic activity. ${ }^{7}$ Given the strong socioeconomic segregation in Santiago (Sabatini et al. 2009; Rodríguez and Arriagada 2004), all models include fixed effects for the sample strata. To account for seasonal and structural changes in hours worked, the model includes fixed effects for the survey quarter and the survey year.

Additional models presented in Additional file 1 explore the relationship with other pollutants and add controls to check the robustness of the results.

The paper focuses primarily on $\mathrm{PM}_{10}$ which has the longest time series across all the monitoring stations. The main results hold for other pollutants which reach high levels in Santiago: $\mathrm{PM}_{2.5}, \mathrm{NO}_{2}$ and $\mathrm{CO}$. The results shown here also hold if the analysis is restricted to the 1997-2006 or 2007-2016 periods. Results remain unaffected if controls for marital status, official temperature and rainfall data ${ }^{8}$ and Google Trends for Internet searches carried out in Chile for the terms influenza, flu, fever and common cold to explore whether infectious diseases more common in fall and winter months are driving 
the results instead. ${ }^{9}$ The results of these robustness checks are discussed in a specific section below.

A model with a full set of controls is not estimated because it would substantially reduce the sample size as several relevant controls are only available for a certain period alone (e.g. income, educational attainment as well as flu and common cold trends).

Standard errors are clustered by survey strata. Sample weights are used as appropriate.

\section{Results}

WHO guidelines (2006) call for annual $\mathrm{PM}_{10}$ concentrations to remain below an average of $20 \mu \mathrm{g} / \mathrm{m}^{3}$. In 2014, one of the years with the lowest air pollution levels observed in the period under study, Santiago's monitoring stations averaged between $50 \mu \mathrm{g} / \mathrm{m}^{3}$ (Las Condes) and $69 \mu \mathrm{g} / \mathrm{m}^{3}$ (El Bosque) over the course of the year. That year, the observed average in the weeks under study was $54.4 \mu \mathrm{g} / \mathrm{m}^{3}$ (Table 2). The yearly average underestimates exposure in the fall and winter months, when pollution, and $\mathrm{PM}_{10}$ levels peak. The 20-year average for the weeks under study that fall in the month of June show a $\mathrm{PM}_{10}$ concentration of $94.4 \mu \mathrm{g} / \mathrm{m}^{3}$ while the months of March, September and December show concentrations of $69.9 \mu \mathrm{g} / \mathrm{m}^{3}, 57.8 \mu \mathrm{g} / \mathrm{m}^{3}$ and $54.0 \mu \mathrm{g} / \mathrm{m}^{3}$, respectively. Also, overall pollution has declined since the late 1990s and early 2000s. While the average $\mathrm{PM}_{10}$ concentration in the weeks under study in 1998 averaged $90.3 \mu \mathrm{g} / \mathrm{m}^{3}$, the concentration over the same weeks declined steadily to $54.4 \mu \mathrm{g} / \mathrm{m}^{3}$ in 2014 . Pre-emergencies, critical episodes declared when $\mathrm{PM}_{10}$ levels exceed $240 \mu \mathrm{g} / \mathrm{m}^{3}$ in any given day tended to be more common in the late 1990s compared to the 2010s, and emergencies (declared when $\mathrm{PM}_{10}$ passes above $330 \mu \mathrm{g} / \mathrm{m}^{3}$ ) happened less frequently after 2007. Figure 1 illustrates this yearly and seasonal variation by showing the daily $\mathrm{PM}_{10}$ levels over the course of the 20 years under study in the Pudahuel monitoring station, located in the south-west of Santiago.

Figure 2 shows that pollution in Santiago is not equally distributed within the city owing to the geography, ventilation conditions and the distribution of industrial and transport activity. Southern and western municipalities (e.g. those represented by the El Bosque monitoring station) tend to experience higher pollution levels compared to the eastern parts of the city (e.g. Las Condes). This is true for $\mathrm{PM}_{10}$ and other pollutants, with the exception of $\mathrm{O}_{3}$ ) (Table 2).

In parallel, since 1997, the employment rate in Santiago has followed the macroeconomic conditions and the expected seasonal variation. Employment fell as a result of the consequences of the Asian financial crisis in the late 1990s, the global recession in the late 2000s and the fall in commodity prices in the 2010s. Male and female employment are sensitive to these fluctuations, but female employment remains, for the majority of the period under study, below 50\% (Table 2). Hours worked are calculated among those that are employed. Despite some seasonal variation, they have tended downwards, to an average of 44 hours per week.

As expected by the socioeconomic segregation in Santiago, employment outcomes also vary geographically. Table 2 also shows the employment rate and hours worked over the period of study across the different geographical areas in Santiago. Employment rates and hours worked are higher among men. Over the entire period under 


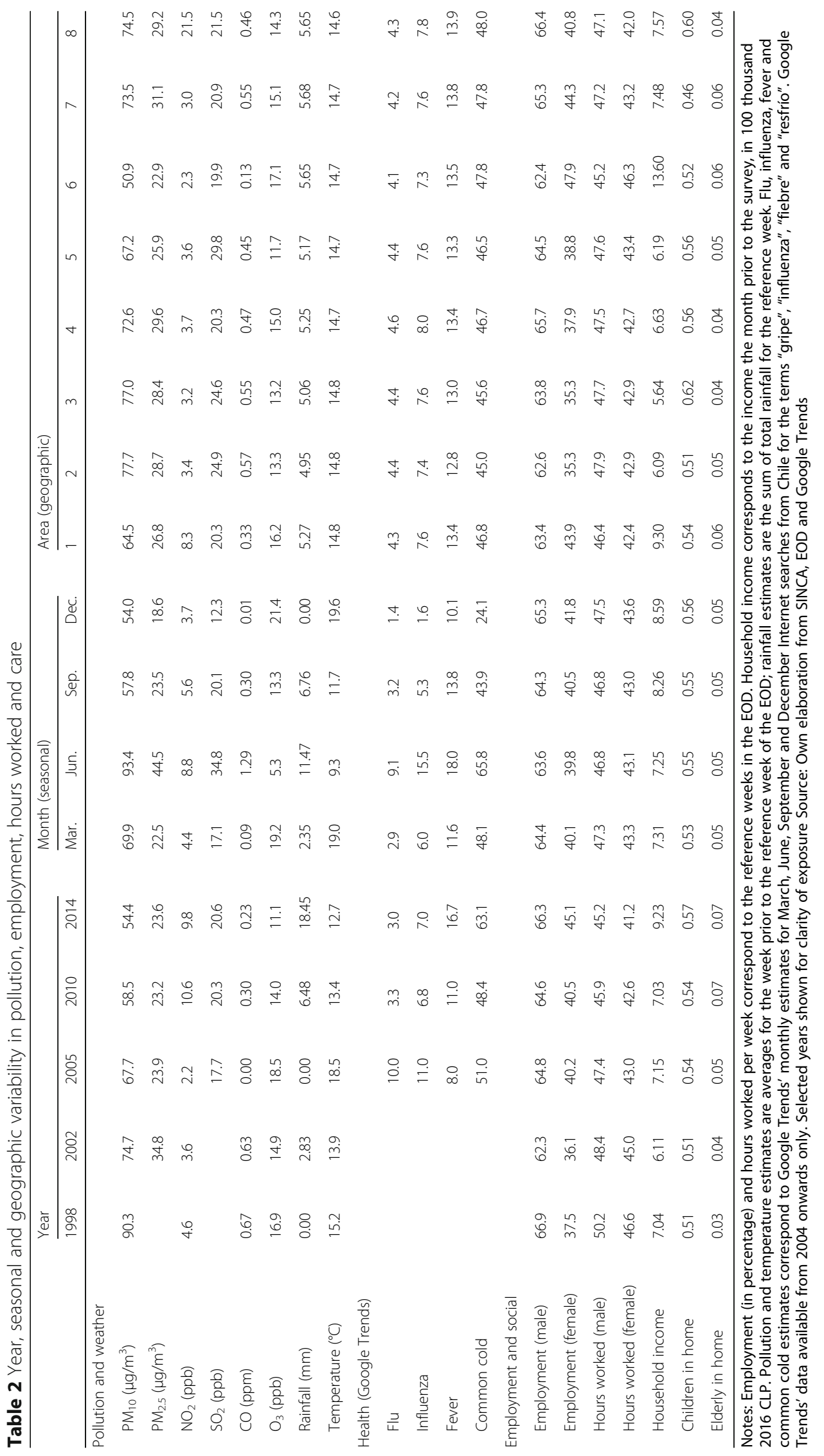




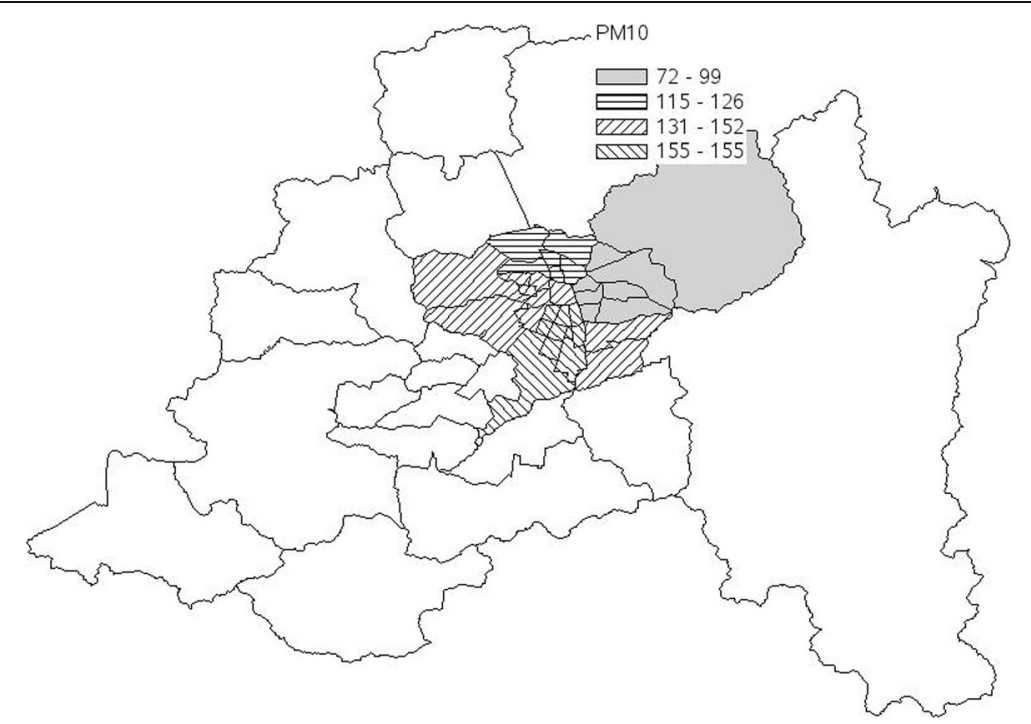

Fig. 2 Geographical distribution of $\mathrm{PM}_{10}$ in Santiago, Chile, 2015. Notes: $\mathrm{PM}_{10}$ in microgrammes per cubic metre. Data for the reference week of June, 2015. Municipalities are grouped by their corresponding strata in the employment survey. Municipalities in white are not covered in the employment survey. Source: Own elaboration from SINCA

study, $64 \%$ of men were employed while $41 \%$ of women were; the average working man worked 47.1 hours per week; the average working woman worked 43.2 hours per week. Employment rates for women are lower in the southern and western municipalities (strata 2, 3, 4 and 5). Hours worked by women per week are relatively similar across strata, except in the higher income, north-eastern municipalities where they are higher (stratum 6).

Household income also mirrors the macroeconomic trends. There are strong geographic inequalities in average household income. While the average income for households in the stratum that includes the wealthy municipalities of Las Condes, Lo Barnechea and Vitacura is higher than 1 million CLP (about 1500 USD), the median household income for household in the stratum that includes the poorer municipalities of El Bosque, La Pintana and San Bernardo is under 600,000 CLP (about 900 USD). Strata comprising the other municipalities have average incomes between these two extremes.

Table 2 also shows the evolution of the number of dependent children per household in Santiago. For the purposes of this study, a dependent child is one who is 14 years old or younger; a dependent elderly is a 60-year-old or older person who lives in a household as a relative or non-relative (i.e. not the head of the household nor the spouse of the household head). The average number of dependent children in the household increased from 0.51 in 1998 and to 0.57 in 2014. The average number of dependent elderly in a household increased from 0.03 in 1998 to 0.07 in 2014. This means that, assuming one dependent elderly per household, the share of households with dependent elderly passed from around 1 out of every 30 to 1 out of every 15 in less than 15 years, a very rapid change in the need for care, as noted by Palacios (2017).

Regression models shown in Table 3 estimate the relationship between air pollution and hours worked. After accounting for structural, cyclical and geographic variation through fixed effects, exposure to $\mathrm{PM}_{10}$ is not, on aggregate and for the whole labour market, associated to a reduction in hours worked ( $\beta_{1}$ in Eq. 1) (model 1). This 
Table 3 The relationship between hours worked, $\mathrm{PM}_{10}$, gender and childcare in Santiago

\begin{tabular}{|c|c|c|c|c|c|}
\hline & Model 1 & Model 2 & Model 3 & Model 4 & Model 5 \\
\hline $\mathrm{PM}_{10}$ & $\begin{array}{l}0.0017 \\
(0.0022)\end{array}$ & $\begin{array}{l}0.0098 \\
(0.0024)^{* * *}\end{array}$ & $\begin{array}{l}0.0195 \\
(0.0050)^{* * *}\end{array}$ & $\begin{array}{l}0.0185 \\
(0.0055)^{* * *}\end{array}$ & $\begin{array}{l}0.0216 \\
(0.0055)^{* * *}\end{array}$ \\
\hline $\mathrm{PM}_{10} \times$ female & & $\begin{array}{l}-0.0216 \\
(0.0025)^{* * *}\end{array}$ & $\begin{array}{l}-0.0259 \\
(0.0027)^{* * *}\end{array}$ & $\begin{array}{l}-0.0167 \\
(0.0036)^{* * *}\end{array}$ & $\begin{array}{l}-0.0196 \\
(0.0039)^{* * *}\end{array}$ \\
\hline $\mathrm{PM}_{10} \times$ female $\times$ children & & & & $\begin{array}{l}-0.0155 \\
(0.0042)^{* * *}\end{array}$ & $\begin{array}{l}-0.0146 \\
(0.0042) * * *\end{array}$ \\
\hline $\mathrm{PM}_{10} \times$ children & & & & $\begin{array}{l}0.0037 \\
(0.0027)\end{array}$ & $\begin{array}{l}0.0029 \\
(0.0027)\end{array}$ \\
\hline Female & & $\begin{array}{l}-2.3423 \\
(0.1863)^{* * *}\end{array}$ & $\begin{array}{l}-2.0167 \\
(0.1949)^{* * *}\end{array}$ & $\begin{array}{l}-1.9649 \\
(0.2682)^{* * *}\end{array}$ & $\begin{array}{l}-1.5014 \\
(0.2814)^{* * *}\end{array}$ \\
\hline Children & & & & $\begin{array}{l}0.8680 \\
(0.2059)^{* * *}\end{array}$ & $\begin{array}{l}0.8827 \\
(0.2040)^{* * *}\end{array}$ \\
\hline Female $\times$ children & & & & $\begin{array}{l}-0.0920 \\
(0.3165)\end{array}$ & $\begin{array}{l}-0.1440 \\
(0.3150)\end{array}$ \\
\hline $\begin{array}{l}\mathrm{PM}_{10} \times \text { female } \times \\
\text { non-working adult }\end{array}$ & & & & & $\begin{array}{l}0.0455 \\
(0.0107)^{* * *}\end{array}$ \\
\hline $\mathrm{PM}_{10} \times$ non-working adult & & & & & $\begin{array}{l}0.0044 \\
(0.0045)\end{array}$ \\
\hline Female $\times$ non-working adult & & & & & $\begin{array}{l}-4.4474 \\
(0.7704)^{* * *}\end{array}$ \\
\hline Non-working adult & & & & & $\begin{array}{l}0.5190 \\
(0.3299)\end{array}$ \\
\hline $\mathrm{PM}_{10} \times$ age & & & $\begin{array}{l}-0.0001 \\
(0.0001)\end{array}$ & $\begin{array}{l}-0.0002 \\
(0.0001)\end{array}$ & $\begin{array}{l}-0.0003 \\
(0.0001)^{*}\end{array}$ \\
\hline $\mathrm{PM}_{10} \times$ agriculture and mining & & & $\begin{array}{l}-0.0114 \\
(0.0098)\end{array}$ & $\begin{array}{l}-0.0125 \\
(0.0098)\end{array}$ & $\begin{array}{l}-0.0115 \\
(0.0098)\end{array}$ \\
\hline $\mathrm{PM}_{10} \times$ manufacturing & & & $\begin{array}{r}-0.0052 \\
(0.0033)\end{array}$ & $\begin{array}{r}-0.0050 \\
(0.0034)\end{array}$ & $\begin{array}{l}-0.0051 \\
(0.0034)\end{array}$ \\
\hline $\mathrm{PM}_{10} \times$ construction & & & $\begin{array}{l}-0.0242 \\
(0.0036)^{* * *}\end{array}$ & $\begin{array}{l}-0.0246 \\
(0.0036)^{* * *}\end{array}$ & $\begin{array}{l}-0.0247 \\
(0.0036)^{* * *}\end{array}$ \\
\hline Age & & & $\begin{array}{l}0.0618 \\
(0.0077)^{* * *}\end{array}$ & $\begin{array}{l}0.0695 \\
(0.0078)^{* * *}\end{array}$ & $\begin{array}{l}0.0715 \\
(0.0082)^{* * *}\end{array}$ \\
\hline Agriculture and mining & & & $\begin{array}{l}1.6833 \\
(0.7011)^{*}\end{array}$ & $\begin{array}{l}1.7784 \\
(0.6995)^{*}\end{array}$ & $\begin{array}{l}1.6894 \\
(0.7005)^{*}\end{array}$ \\
\hline Manufacturing & & & $\begin{array}{l}0.6568 \\
(0.2429)^{* *}\end{array}$ & $\begin{array}{l}0.6041 \\
(0.2432)^{*}\end{array}$ & $\begin{array}{l}0.5967 \\
(0.2433)^{*}\end{array}$ \\
\hline Construction & & & $\begin{array}{l}1.2886 \\
(0.2719)^{* * *}\end{array}$ & $\begin{array}{l}1.2313 \\
(0.2722)^{* * *}\end{array}$ & $\begin{array}{l}1.2235 \\
(0.2723)^{* * *}\end{array}$ \\
\hline N & 255,419 & 255,419 & 255,419 & 255,419 & 255,419 \\
\hline$R$-squared & 0.0123 & 0.0275 & 0.0300 & 0.0321 & 0.326 \\
\hline Year, quarter, area fixed effects & Yes & Yes & Yes & Yes & Yes \\
\hline
\end{tabular}

${ }^{*} p<0.05,{ }^{* *} p<0.01,{ }^{* * *} p<0.001$

Notes: Robust standard errors in parentheses. $\mathrm{PM}_{10}$ measured in microgrammes per cubic metre Source: Own calculation based on EOD and SINCA, 1997-2017

aggregate relationship masks differences by gender: when air pollution rises, women reduce their hours worked while men increase their hours worked: the estimate for $\mathrm{PM}_{10}$ $\times$ female $\left(\beta_{2}\right.$ in Eq. 2$)$ is negative while the estimate for $\mathrm{PM}_{10}$, which corresponds to the relationship between $\mathrm{PM}_{10}$ and hours worked when the interaction is included in the model, is positive ( $\beta_{1}$ in Eq. 2) (model 2). For each $100 \mu \mathrm{g} / \mathrm{m}^{3}$ increase in a week's $\mathrm{PM}_{10}$, women reduce, on average, their work week by 2.2 hours while men increase theirs by 1 hour. These analyses speak to the general aggregate pattern; it is not clear 
whether men compensate for women's reduced working hours in the household (it is the spouse who works late when a woman works less) or in the workplace (it is the male colleagues who work late when a female colleague goes home early or takes leave when pollution increases). Given that employment rates for men are higher than women's, men's smaller increase over a larger employed population compensates for women's larger reduction over a smaller employed population.

A week characterised by recurrent episodes of Alerta ambiental (set at $195 \mu \mathrm{g} / \mathrm{m}^{3}$ ) is expected to see women work an additional 4.3 fewer hours than men. These coefficients are important in magnitude. They compare to a 4.0 difference in average hours worked per week between men and women when $\mathrm{PM}_{10}$ concentration is nil. Another way to view the magnitude of these coefficients is that a week with pollution at $100 \mu \mathrm{g} / \mathrm{m}^{3}$ increases the gender difference in working hours by half compared to a baseline low polluted day; a week with recurrent episodes of Alerta ambiental doubles the gender difference in working hours.

Such levels of pollution are not uncommon. Of the 1068 weeks with $\mathrm{PM}_{10}$ measurements considered in this study, the weekly average surpassed $100 \mu \mathrm{g} / \mathrm{m}^{3}$ on 213 weeks in the El Bosque monitoring station, 193 weeks in the Parque O'Higgins monitoring station, 192 weeks in the Pudahuel monitoring station and 189 weeks in the La Florida monitoring station. The Las Condes monitoring station, situated on the north-east side of the city which hosts the majority of the upper-income population, only averaged pollution levels above or equal to $100 \mu \mathrm{g} / \mathrm{m}^{3}$ on 20 weeks.

Model 3 adds controls for age and economic sector. Gender results hold. Model 3 also suggests that the association between air pollution and working hours does not differ by age (estimate for $\mathrm{PM}_{10} \times$ age). Air pollution is associated to lower working hours among workers in the construction sector more strongly than workers in other industries, may be because of their higher exposure to urban outdoor air pollution and/or because during episodes of critical air pollution (declared when $\mathrm{PM}_{10}$ levels exceed $240 \mu \mathrm{g} / \mathrm{m}^{3}$ ) freight transport within the inner city radius is prohibited (Ministerio del Medio Ambiente 2018).

A large part of the gender-related difference in hours worked is driven by childcare (model 4). The estimate associated to $\mathrm{PM}_{10} \times$ female interaction, which captures the differential association of pollution on women compared to men, is reduced from -0.259 in model 2 to -0.0167 ; it remains significant at the $p<0.001$ level. The estimate associated to the gender-children- $\mathrm{PM}_{10}$ interaction, which captures the differential effect of pollution on women with children, absorbs most of this difference. For each child in the home, women are expected to see their weekly hours worked reduced, on average, by 1.6 hours per week when $\mathrm{PM}_{10}$ increases by $100 \mu \mathrm{g} / \mathrm{m}^{3}$.

These results are consistent with the fact that when air pollution increases, more children fall sick and are not able to go to school. They must be cared for at home (Park et al. 2002; Currie et al. 2009). If no other care arrangement exists (e.g. a nanny, a non-working adult in the household), someone in the family must care for the child. The estimate for men $\left(\mathrm{PM}_{10} \times\right.$ children) is not significant, suggesting that pollution-childcare-hours worked nexus applies only to women. This is consistent with the gendered family care arrangement that prevails in Chile (Martínez Franzoni 2008; Palacios 2017). When pollution increases and children fall sick, it is usually women within the family who reduce their working hours to care for them. ${ }^{10}$

Women with no children are also expected to see a small reduction in their working hours when air pollution increases (at 1.7 hours per week, on average). This negative 
estimate observed on women with no children could be the result of air pollution's direct effect on women's health or could operate through other care demands (e.g. care for a dependent elderly who fall ill as a result of pollution).

Model 5 confirms the idea that the gendered effect of air pollution on hours worked is driven, to a large extent, by childcare. The differential estimates of air pollution on women with children $\left(\mathrm{PM}_{10} \times\right.$ female $\times$ children) is largely nil for working women who have another non-working adult in the home who could, potentially care for the sick child (the $\mathrm{PM}_{10} \times$ female $\times$ non-working adult estimate is positive and higher in absolute value than the estimate for $\mathrm{PM}_{10} \times$ female $\times$ children). For women with one child and no non-working adults in the household, a $100 \mu \mathrm{g} / \mathrm{m}^{3}$ increase in $\mathrm{PM}_{10}$ concentration is associated to an average 3.4 fewer hours worked than men; this difference is 4.9 for a woman with two children. This difference disappears among women with non-working adults in the home.

Table 4 replicates model 4 in Table 3 but considers elderly care instead of childcare. Elderly living in the home may be dependent, requiring care. In Chile, this care is usually carried out by family members. Like children, the elderly are particularly vulnerable to the negative health effects of outdoor air pollution. Unlike the estimates for children, however, having elderly in the home is not associated to a reduction in women's hours worked. This could be explained by the fact that co-habiting elderly may not, in general, be affected by air pollution levels like those observed in Santiago. Alternatively, if they are dependent, someone is already taking care of them, as Chile generally lacks institutional alternatives to support the dependent elderly (Palacios 2017). Care is thus provided in the home by, generally, a daughter or a paid caregiver. This arrangement works when the elderly is healthy and does not change when the elderly's health deteriorates due to air pollution. If the elderly fall sick, this should not affect working women's ability to work. In contrast, healthy children are cared for at school, and this care arrangement does not work when children are ill, leading some to work fewer hours.

Table 4 also replicates model 4 in Table 3 for other commonly measured air pollutants $\left(\mathrm{PM}_{2.5}, \mathrm{SO}_{2}, \mathrm{NO}_{2}, \mathrm{O}_{3}\right.$ and $\left.\mathrm{CO}\right)$. The general pattern observed for $\mathrm{PM}_{10}$ in which a higher number of children in the home are associated to fewer hours worked by women when pollution increases holds for $\mathrm{PM}_{2.5}$ and $\mathrm{CO}$ (negative and significant pollutant $\times$ female $\times$ children estimates). It is non-significant for $\mathrm{NO}_{2}$ (the point estimate is negative) and positive for $\mathrm{SO}_{2}$ and $\mathrm{O}_{3}$. The different patterns observed with $\mathrm{SO}_{2}$ and $\mathrm{O}_{2}$ could be due to the fact that $\mathrm{SO}_{2}$ and $\mathrm{O}_{3}$ levels are generally low in Santiago compared to other urban areas (O'Ryan and Larraguibel 2000) and to the fact that $\mathrm{SO}_{2}$ levels were particularly low during the weeks prior to the EOD survey (see Additional file 1: Figure S1). For $\mathrm{SO}_{2}$ and $\mathrm{O}_{3}$, there may not be enough observed variation in Santiago to capture its negative health effects on children. ${ }^{11}$

\subsection{Robustness checks}

The general results observed for $\mathrm{PM}_{10}$ hold when restricting the sample to the 1997-2006 and 2007-2017 periods (Additional file 1: Table S2). They also hold after controlling for marital status and the hours worked by other members in the household. They hold partially after controlling for educational attainment (though the estimate for the $\mathrm{PM}_{10} \times$ 
Table 4 The relationship between hours worked, gender and childcare, elderly care and other outdoor air pollutants in Santiago

\begin{tabular}{|c|c|c|c|c|c|c|}
\hline \multirow{2}{*}{$\begin{array}{l}\text { Dependant } \\
\text { Pollutant }\end{array}$} & \multirow{2}{*}{$\begin{array}{l}\text { Elderly } \\
\mathrm{PM}_{10}\end{array}$} & \multicolumn{5}{|l|}{ Children } \\
\hline & & $\mathrm{PM}_{2.5}$ & $\mathrm{SO}_{2}$ & $\mathrm{NO}_{2}$ & $\mathrm{O}_{3}$ & $\mathrm{CO}$ \\
\hline Poll. & $\begin{array}{l}0.0202 \\
(0.0050)^{* * *}\end{array}$ & $\begin{array}{l}0.0062 \\
(0.0110)\end{array}$ & $\begin{array}{l}-0.0392 \\
(0.0191)^{*}\end{array}$ & $\begin{array}{l}-0.0096 \\
(0.0158)\end{array}$ & $\begin{array}{l}0.0428 \\
(0.0211)^{*}\end{array}$ & $\begin{array}{l}0.0923 \\
(0.2314)\end{array}$ \\
\hline Poll. $\times$ female & $\begin{array}{l}-0.0269 \\
(0.0028)^{* * *}\end{array}$ & $\begin{array}{l}-0.0144 \\
(0.0075)\end{array}$ & $\begin{array}{l}-0.0557 \\
(0.0122)^{* * *}\end{array}$ & $\begin{array}{l}-0.0065 \\
(0.0105)\end{array}$ & $\begin{array}{l}0.0372 \\
(0.0131)^{* *}\end{array}$ & $\begin{array}{l}-0.2066 \\
(0.1424)\end{array}$ \\
\hline $\begin{array}{l}\text { Poll. } \times \text { female } \times \\
\text { dependent }\end{array}$ & $\begin{array}{l}0.0209 \\
(0.0149)\end{array}$ & $\begin{array}{l}-0.0254 \\
(0.0092)^{* *}\end{array}$ & $\begin{array}{l}0.0374 \\
(0.0140)^{* *}\end{array}$ & $\begin{array}{l}-0.0154 \\
(0.0117)\end{array}$ & $\begin{array}{l}-0.0112 \\
(0.0163)\end{array}$ & $\begin{array}{l}-0.5799 \\
(0.1768) * * *\end{array}$ \\
\hline Poll. $\times$ dependent & $\begin{array}{l}-0.0081 \\
(0.0076)\end{array}$ & $\begin{array}{l}0.0102 \\
(0.0058)\end{array}$ & $\begin{array}{l}-0.0339 \\
(0.0060)^{* * *}\end{array}$ & $\begin{array}{l}-0.0096 \\
(0.0061)\end{array}$ & $\begin{array}{l}0.0252 \\
(0.0108)^{*}\end{array}$ & $\begin{array}{l}0.1934 \\
(0.1111)\end{array}$ \\
\hline Female & $\begin{array}{l}-1.9965 \\
(0.2035)^{* * *}\end{array}$ & $\begin{array}{l}-2.5897 \\
(0.2348)^{* * *}\end{array}$ & $\begin{array}{l}-2.8048 \\
(0.1385)^{* * *}\end{array}$ & $\begin{array}{l}-2.8961 \\
(0.2628)^{* * *}\end{array}$ & $\begin{array}{l}-3.6705 \\
(0.1993)^{* * *}\end{array}$ & $\begin{array}{l}-3.0338 \\
(0.1125) * * *\end{array}$ \\
\hline Dependent & $\begin{array}{l}-0.4175 \\
(0.5606)\end{array}$ & $\begin{array}{l}0.8048 \\
(0.1827)^{* * *}\end{array}$ & $\begin{array}{l}1.5405 \\
(0.1101)^{* * *}\end{array}$ & $\begin{array}{l}1.0371 \\
(0.1487)^{* * *}\end{array}$ & $\begin{array}{l}0.7564 \\
(0.1513)^{* * *}\end{array}$ & $\begin{array}{l}1.0504 \\
(0.0951)^{* * *}\end{array}$ \\
\hline Female $\times$ dependent & $\begin{array}{l}-0.4290 \\
(1.1012)\end{array}$ & $\begin{array}{l}-0.2680 \\
(0.2862)\end{array}$ & $\begin{array}{l}-1.6427 \\
(0.1794)^{* * *}\end{array}$ & $\begin{array}{l}-0.3217 \\
(0.2939)\end{array}$ & $\begin{array}{l}-0.9012 \\
(0.2348)^{* * *}\end{array}$ & $\begin{array}{l}-0.8932 \\
(0.1422)^{* * *}\end{array}$ \\
\hline Poll. $\times$ age & $\begin{array}{l}-0.0001 \\
(0.0001)\end{array}$ & $\begin{array}{l}0.0001 \\
(0.0002)\end{array}$ & $\begin{array}{l}0.0016 \\
(0.0004)^{* * *}\end{array}$ & $\begin{array}{l}0.0005 \\
(0.0003)\end{array}$ & $\begin{array}{l}-0.0013 \\
(0.0004)^{* * *}\end{array}$ & $\begin{array}{l}-0.0034 \\
(0.0044)\end{array}$ \\
\hline Poll. $\times$ agriculture and mining & $\begin{array}{l}-0.0115 \\
(0.0098)\end{array}$ & $\begin{array}{l}-0.0223 \\
(0.0223)\end{array}$ & $\begin{array}{l}0.0661 \\
(0.0346)\end{array}$ & $\begin{array}{l}0.0254 \\
(0.0284)\end{array}$ & $\begin{array}{l}-0.0900 \\
(0.0324)^{* *}\end{array}$ & $\begin{array}{l}-0.7858 \\
(0.4046)\end{array}$ \\
\hline Poll. $\times$ manufacturing & $\begin{array}{l}-0.0052 \\
(0.0034)\end{array}$ & $\begin{array}{l}-0.0130 \\
(0.0065) *\end{array}$ & $\begin{array}{l}0.0210 \\
(0.0127)\end{array}$ & $\begin{array}{l}-0.0156 \\
(0.0101)\end{array}$ & $\begin{array}{l}-0.0017 \\
(0.0111)\end{array}$ & $\begin{array}{l}-0.1508 \\
(0.1359)\end{array}$ \\
\hline Poll. $\times$ construction & $\begin{array}{l}-0.0243 \\
(0.0036)^{* * *}\end{array}$ & $\begin{array}{l}-0.0294 \\
(0.0076)^{* * *}\end{array}$ & $\begin{array}{l}0.0234 \\
(0.0127)\end{array}$ & $\begin{array}{l}-0.0324 \\
(0.0111)^{* *}\end{array}$ & $\begin{array}{l}0.0354 \\
(0.0132) * *\end{array}$ & $\begin{array}{l}-1.0496 \\
(0.1539)^{* * *}\end{array}$ \\
\hline Age & $\begin{array}{l}0.0627 \\
(0.0077) * * *\end{array}$ & $\begin{array}{l}0.0687 \\
(0.0067)\end{array}$ & $\begin{array}{l}0.0445 \\
(0.0039) * * *\end{array}$ & $\begin{array}{l}0.0641 \\
(0.0078)\end{array}$ & $\begin{array}{l}0.0766 \\
(0.0058)^{* * *}\end{array}$ & $\begin{array}{l}0.0603 \\
(0.0032)^{* * *}\end{array}$ \\
\hline Agriculture and mining & $\begin{array}{l}1.6786 \\
(0.7006)^{*}\end{array}$ & $\begin{array}{l}1.6365 \\
(0.6551) *\end{array}$ & $\begin{array}{l}0.8238 \\
(0.3435)^{*}\end{array}$ & $\begin{array}{l}1.1083 \\
(0.7093)\end{array}$ & $\begin{array}{l}2.2368 \\
(0.5185)^{* * *}\end{array}$ & $\begin{array}{l}1.1929 \\
(0.2820)^{* * * *}\end{array}$ \\
\hline Manufacturing & $\begin{array}{l}0.6557 \\
(0.2429) * *\end{array}$ & $\begin{array}{l}0.6852 \\
(0.2051)^{* * *}\end{array}$ & $\begin{array}{l}0.1858 \\
(0.1137)\end{array}$ & $\begin{array}{l}0.7504 \\
(0.2490) * *\end{array}$ & $\begin{array}{l}0.2866 \\
(0.1747)\end{array}$ & $\begin{array}{l}0.3342 \\
(0.0949)^{* * * *}\end{array}$ \\
\hline Construction & $\begin{array}{l}1.2853 \\
(0.2722) * * *\end{array}$ & $\begin{array}{l}0.7027 \\
(0.2360)^{* *}\end{array}$ & $\begin{array}{l}-0.7260 \\
(0.1468)\end{array}$ & $\begin{array}{l}0.7628 \\
(0.2757) * *\end{array}$ & $\begin{array}{l}-0.9738 \\
(0.2035)^{* * *}\end{array}$ & $\begin{array}{l}-0.0195 \\
(0.1196)\end{array}$ \\
\hline N & 255,419 & 177,035 & 196,534 & 115,865 & 253,670 & 254,420 \\
\hline$R$-squared & 0.0301 & 0.0311 & 0.0319 & 0.0280 & 0.0315 & 0.0322 \\
\hline Year, quarter, area fixed effects & YES & YES & YES & YES & YES & YES \\
\hline
\end{tabular}

${ }^{*} p<0.05,{ }^{* *} p<0.01,{ }^{* * *} p<0.001$

Notes: Robust standard errors in parenthesis. The variables included in each model depend on the column. Column names indicate the pollutants included as independent variables and in the interactions (Poll. variables, to be replaced by $\mathrm{PM}_{10}, \mathrm{PM}_{2.5}, \mathrm{SO}_{2}, \mathrm{NO}_{2}, \mathrm{O}_{3}$ or $\mathrm{CO}$ ) as well as the dependent being cared for (Dependent variables, to be replaced by elderly or children). $\mathrm{PM}_{10}$ and $\mathrm{PM}_{2.5}$ measured in microgrammes per cubic metre; $\mathrm{SO}_{2}, \mathrm{O}_{3}$ and $\mathrm{NO}_{2}$ measured in parts per billion; $\mathrm{CO}$ measured in parts per million

Source: Own calculation based on EOD and SINCA, 1997-2017

female $\times$ children interaction is non-significant, it is negative and at the border of statistical significance with an estimated $p$-value of 0.062). Results do not hold for income (Additional file 1: Table S3). The fact that they do not hold for income or educational attainment may signal an important interaction with paid caregivers. If higher educational attainment and higher income make a household more likely to be able to pay for a caregiver (as is the case with the employment of domestic workers in Chile), the constraining factor of children's illness in a woman's ability to work may disappear in households able to pay for this work. The unavailability of domestic employment data and the limited availability of income data in the EOD make testing for this hypothesis difficult. 
Additional file 1: Table S4 adds controls for other weather and flu/common cold epidemics. As pollution in Santiago peaks in the winter months, it may be that cold temperatures and rain which are also more common in the winter months, not pollution, drive the results. Model 1 in Additional file 1: Table S4 controls for the average temperature and total rainfall in the week prior to the EOD reference week; the main results discussed above hold. Flu and common colds are also more common during months in which pollution peaks and may be driving the results instead. Model 2 in Additional file 1: Table S4 adds controls for Google Trends for Internet searches related to the terms "gripe" and "resfrio", which translate to "flu" and "common cold"; they accurately predict the distribution of flu epidemics (Ginsberg et al. 2009). Google Trends data are available since 2004, and their inclusion does not alter the results. All previous models add year and quarter fixed effects. A final model that adds year $\times$ quarter fixed effects does not alter the main results discussed in this paper (model 3 in Additional file 1: Table S4).

\section{Conclusions}

This paper draws on 20 years of systematic data collection on employment and air pollution to explore the link between air pollution and hours worked. Findings suggest that, on the aggregate, air pollution in the levels commonly observed in Santiago, Chile, does not reduce overall hours worked. The findings are unlike those observed in Peru (Aragon et al. 2017), India (ASSOCHAM 2016) or Indonesia (Kim et al. 2017), which do report a drop in overall hours worked. They draw on a different research design, a shorter time period of analysis or the analysis of more extreme pollution events.

The lack of an overall reduction in hours worked may be also be due to the fact that given the long tradition of air pollution in Santiago (O'Ryan and Larraguibel 2000), individuals are more familiar with actions to reduce outdoor air pollution's health effects, reducing the impact of air pollution on working adults' health.

This general trend hides, however, an important gendered relationship. Women, and women with children in particular, tend to reduce their hours worked in weeks of high pollution, and there is some indication that this reduction is compensated by men, so that the aggregate association is nil. Air pollution seems to accentuate labour market inequalities, as is the case for other forms of environmental degradation (ILO 2018).

This gendered relationship is rooted in the inequalities in the distribution of care obligations and perpetuates gender inequalities in the labour market. Chile is noted as an exception, as the high levels of female educational attainment have not allowed for a stronger labour force participation, with the gendered perceptions of caring responsibilities having a prominent role in explaining gender-related labour market outcomes (Contreras et al. 2012). Workers who work fewer hours are less likely to earn a promotion, particularly in countries with high levels of inequality (Bell and Freeman 2001). Policy that reduces air pollution and its effects on children's health also serves to advance gender equality in the labour market.

The results in this study find a relationship between air pollution and hours worked through gender and childcare, but not through elderly care. Though both children and the elderly's health are especially sensitive to air pollution, this finding does not mean that elderly care is unrelated to labour supply more generally. This study estimates the relationship on hours worked, assuming that the carer for the sick child or elderly 
works for pay. However, the lack of policies to support elderly care mean that elderly carers are generally out of the labour force altogether (Palacios 2017). Were policies to support elderly care develop in Chile (e.g. day centres) and allow carers to work for pay at the same time, air pollution may affect their hours worked like it does for parents when their children cannot attend school.

These findings, and the data on which they are based, do not speak to the long-term effects of exposure to sustained or peak air pollution, which do exist (Kim et al. 2017). Unfortunately, the household income data in the employment survey does not allow for a robust assessment of the extent to which income attenuates the care-related association seen in the regression models. It could be the case, for example, that this care-related pollution association with women's work does not apply to high-income households who employ housemaids. Full-time housemaids can, when children fall sick, add caring duties to their usual work. Full-time housemaids are common in Latin America and other parts of the world. Usually, their work involves flexibility in the number and type of tasks to be carried out so housemaids can care for sick dependents on a sporadic basis if needed (Stefoni 2009; Palacios 2017).

Several policies can help reduce the gendered association of air pollution on hours worked, as they operate mostly through care and dependent's health. First and foremost, policies to reduce air pollution, and air pollution peaks in particular, will eliminate this source of gender inequality. This requires addressing the main sources of air pollution: inefficient fossil fuel combustion from motor vehicles and power generation, improve energy efficiency in buildings and manufacturing and reduce the sources of solid particulates (WHO 2010). Policies can also help reduce the health impacts given air pollution levels, which will reduce children's risk of illness. These include reducing exposure to ambient air pollution by staying indoors, reducing outdoor air infiltration indoors, cleaning indoor air with air filters and limiting physical exertion (Laumbach et al. 2015). Finally, if air pollution and children's deteriorated health are given, policies can also help reduce the gendered relationship by promoting a more equal distribution of care across gender, as outlined by Contreras et al. (2012) for the specific case of Chile.

Future research should explore in more detail the relationship between air pollution, hours worked and income, insofar mitigation policies could also be considered pro-poor and contribute to social equity. Future research could also examine care for dependent's mediating role in the relationship between air pollution and female hours worked by checking the effect of air pollution on school attendance, for example. Future research could explore the link with the construction sector in detail, as may allow to distinguish labour demand and labour supply factors given the restrictions associated to freight transport when pollution reaches critical levels. Future research should also explore the generalizability of these findings to other social contexts and care regimes by applying the methodology to cities in developed countries as well as cities in other emerging and developing countries and by complementing these results to measures of indoor air pollution.

\section{Endnotes}

${ }^{1}$ To facilitate exposure, in the remaining of the paper, urban outdoor air pollution is referred to as "air pollution" or "pollution". 
${ }^{2}$ Lead is another powerful urban outdoor pollutant which can adversely affect the nervous system, kidney function, the immune system, reproductive and developmental systems and the cardiovascular system. Children are particularly sensitive to lead accumulation in the blood and bones, leading to cognitive deficiencies and behavioural problems (EPA 2017). Lead pollution in Chile is considered low as a result of the introduction of lead-free gasoline in 1993 and its abolishment in 2001. By 1998, lead levels in infants had decreased considerably (O'Ryan and Larraguibel 2000).

${ }^{3}$ An additional channel, not explored in this paper, is the reduction in natural assets caused by air pollution affecting the availability of work. Airborne pollutants, for example, affect plant growth and agricultural productivity (Unsworth and Ormrod 1982).

${ }^{4}$ Palacios (2017) notes that around $90 \%$ of the dependent elderly in Chile have a family member as the main caregiver. Only a minority rely on institutional care (e.g. nursing homes) or are able to pay nurses or housemaids to this effect.

${ }^{5}$ The WHO's Outdoor Air Pollution Database (2016) ranks Santiago 12th in $\mathrm{PM}_{2.5}$ concentration (over a total of 576 cities) and 119th in PM $_{10}$ concentration (over a total of 1099 cities), with the highest-ranking cities being the most polluted.

${ }^{6}$ Though restricted to Santiago, results are likely to hold for other Chilean cities with pollution levels observed since 1997 in Santiago (e.g. Concepción, Coyhaique, Temuco and Osorno, among others in WHO, 2016) and to other Latin American cities with pollution levels and similar care regimes (for a discussion on care regimes in Chile and Latin America, see Martínez Franzoni (2008)).

${ }^{7}$ Models testing for children as defined by different age groups do not substantially change the results. Models that add the age of the youngest child in the home as a control does not affect the results either.

${ }^{8}$ Temperature and rainfall data extracted from Chile's national weather agency (Dirección Meteorológica de Chile): https://climatologia.meteochile.gob.cl .

${ }^{9}$ Ginsberg et al. (2009) demonstrate how flu epidemics can be predicted using Google search trends.

${ }^{10}$ Though this is the most likely explanation, it could also be the result of women falling sick because they care. If they interact more with children, as evidenced by time-use surveys, and interact more with sick children, they are more likely to fall sick due to contagion (INE 2016). Yet, even if men interact less with children, their interaction with women would facilitate contagion as well, which would be observed in a decline in men's working hours as well.

${ }^{11} \mathrm{WHO}$ guidelines for $\mathrm{SO}_{2}$ are set at $20 \mu \mathrm{g} / \mathrm{m}^{3}$ for a 24-h mean and are set for $\mathrm{O}_{3}$ at $100 \mu \mathrm{g} / \mathrm{m}^{3}$ for an 8-h mean. SINCA measures $\mathrm{SO}_{2}$ and $\mathrm{O}_{3}$ in parts per billion, which at $25{ }^{\circ} \mathrm{C}$ temperature and $1013 \mathrm{mb}$ air pressure correspond to $7.6 \mathrm{ppb}$ and $51 \mathrm{ppb}$, respectively (WHO 2006). Additional file 1: Figure S1 suggests that very few days in the weeks prior to the reference week reached or passed these threshold levels.

\section{Additional file}

Additional file 1: Figure S1. Air pollution trends for non-PM10 pollutants, Santiago, Chile, 1997-2017. Table S1. Correlation between daily measurements of pollutants in Santiago, Chile, 1997-2017. Table S2. Robustness check: Restricting the sample to the 1997-2006 and 2007-2016 periods. Table S3. Robustness check: Controls for income, educational attainment and marital status. Table S4. Robustness check: Controls for rainfall, temperature and health trends. (DOCX $212 \mathrm{~kb})$ 


\section{Acknowledgements}

The author thanks Cynthia van Lamoen and the staff at Centro Microdatos (Universidad de Chile) for providing the specific reference weeks for each employment survey and for facilitating access to the survey. The author also thanks Silas Amo-Agyei, Andrés Biehl, Michela Esposito, Marek Harsdorff, Catherine Saget, the participants at the ILO's Brownbag Research Seminar, two anonymous reviewers and the editor for insightful comments. All errors remain the author's sole responsibility. The responsibility for opinions expressed in this article rests solely with its author, and publication does not constitute an endorsement by the International Labour Office of the opinions expressed in it.

Responsible editor: Pierre Cahuc

\section{Competing interests}

The IZA Journal of Labor Economics is committed to the IZA Guiding Principles of Research Integrity. The author declares that he has observed these principles.

\section{Publisher's Note}

Springer Nature remains neutral with regard to jurisdictional claims in published maps and institutional affiliations.

\section{Received: 21 March 2018 Accepted: 7 August 2018}

Published online: 28 August 2018

\section{References}

AAP (American Academy of Pediatrics) (2004) Ambient air pollution: health hazards to children. Pediatrics 114(6):1699-1707

Aragon FM, Miranda JJ, Oliva P (2017) Particulate matter and labor supply: the role of caregiving and non-linearities. J Environ Econ Manag 86:295-309

ASSOCHAM (2016) Smog hitting employees at India Inc. hard and fast in Delhi-NCR: survey. The Associated Chambers of Commerce \& Industry of India, New Delhi

Bell LA, Freeman RB (2001) The incentive for working hard: explaining hours worked differences in the US and Germany. Labour Econ 8(2):181-202

Contreras D, Hurtado A, Sara MF (2012) La excepción Chilena y las percepciones de género en la participación laboral femenina. In: Documentos de Trabajo, No. 374. Departmento de Economía, Universidad de Chile

Currie J, Hanushek E, Kahn M, Neidell M, Rivkin S (2009) Does pollution increase school absences? Rev Econ Stat 91(4):682694

EPA (2017) Basic information about lead air pollution. Environmental Protection Agency, Washington, DC

Eriksson R, Nermo M (2010) Care for sick children as a proxy for gender equality in the family. Soc Indic Res 97(3):341-356

Ginsberg J, Mohebbi MH, Patel RS, Brammer L, Smolinski MS, Brilliant L (2009) Detecting influenza epidemics using search engine query data. Nature 457:1012-1014

Heymann SJ, Penrose K, Earle A (2006) Meeting children's needs: how does the United States measure up? Merrill-Palmer Q 52(2):189-215

Hollingsworth B, Ohinata A, Picchio M, Walker I (2017) Labour supply and informal care supply: the impacts of financial support for long-term elderly care. In: IZA discussion paper series, no. 10988

ILO (2018) WESO 2018: greening with jobs. International Labour Office, Geneva Forthcoming

INE (2016) Encuesta nacional sobre uso del tiempo. Instituto Nacional de Estadísticas, Santiago

Kim Y, Manley J, Radoias V (2017) Medium- and long-term consequences of pollution on labor supply: evidence from Indonesia. IZA J Labor Econ 6(1):5

Laumbach R, Meng Q, Kipen H (2015) What can individuals do to reduce personal health risks from air pollution? J Thoracic Dis 7(1):96-107

Martínez Franzoni J (2008) Welfare regimes in Latin America: capturing constellations of markets, families, and policies. Latin Am Pol Soc 50(2):67-100

Ministerio del Medio Ambiente (2018) Plan operacional para la gestión de episodios críticos de contaminación atmosférica por material particulado respirable en la Región Metropolitana, Santiago

Muñoz M (1991) La contaminación atmosférica en Santiago: impacto sobre la salud de su población. Centro de Estudios Públicos

O'Ryan R, Larraguibel L (2000) Contaminación del aire en Santiago: Estado actual y soluciones, No. 75. Centro de Economía Aplicada, Universidad de Chile

OECD (2014a) The cost of air pollution: health impacts of road transport. OECD Publishing, Paris

OECD (2014b) Unpaid care work: the missing link in the analysis of gender gaps in labour outcomes. Organisation for Economic Co-operation and Development, Paris

OECD (2016a) The economic consequences of outdoor air pollution. OECD Publishing, Paris

OECD (2016b) Education at a Glance 2016. OECD Publishing, Paris

Palacios J (2017) Caring for the elderly in Chile. University of Rennes, Rennes

Park H, Lee B, Ha E-H, Lee J-T, Kim H, Hong Y-C (2002) Association of air pollution with school absenteeism due to illness, Archives of Pediatrics \& Adolescent Medicine 156(12):1235-1239

Rodríguez J, Arriagada C (2004) Segregación residencial en la ciudad latinoamericana. EURE 30(89):05-24

Romley J, Hackbarth A, Goldman D (2010) The impact of air quality on hospital spending. RAND Corporation, Santa Monica

Sabatini F, Wormald G, Sierralta C, Peters PA (2009) Residential segregation in Santiago: scale-related effects and trends, 1992-2002. In: Roberts BR, Wilson RH (eds) Urban segregation and governance in the Americas. Palgrave Macmillan US, pp 121-143

Stefoni C (2009) Migración, género y servicio doméstico: Mujeres peruanas en Chile. In: Trabajo Doméstico: Un Largo Camino Hacia El Trabajo Decente. Organización Internacional del Trabajo, Santiago, pp 191-232

Unsworth MH, Ormrod DP (1982) Effects of gaseous air pollution in agriculture and horticulture. Butterworth Scientific, London 
WHO (2006) Air quality guidelines for particulate matter, ozone, nitrogen dioxide and sulphur dioxide: global update 2005. World Health Organization, Geneva

WHO (2010) Exposure to air pollution: a major public health concern. World Health Organization, Geneva

WHO (2016) Urban ambient air pollution database: update 2016. World Health Organization, Geneva

WHO; OECD (2015) Economic cost of the health impact of air pollution in Europe: clean air, health and wealth. WHO Regional Office for Europe, Copenhagen

World Bank; Institute for Health Metrics and Evaluation (2016) The cost of air pollution: strengthening the economic case for action. The World Bank Group, Washington DC

Submit your manuscript to a SpringerOpen ${ }^{0}$ journal and benefit from:

- Convenient online submission

- Rigorous peer review

- Open access: articles freely available online

High visibility within the field

Retaining the copyright to your article

Submit your next manuscript at $>$ springeropen.com 